\title{
Opplæring i hjerte-lunge-redning i sykehus
}

\section{Nesten alle sykehusansatte kan lære hjerte-lunge-redning med minimal tidsbruk og uten bruk av instruktør. Det viser en studie fra Stavanger.}

Plutselig uventet hjertestans er en dramatisk hendelse som krever umiddelbar varsling og oppstart av basal hjerte-lunge-redning. Om lag hver tredje hjertestans skjer i sykehus. Norsk Resuscitasjonsråd har som mål at alt sykehuspersonell skal kunne gjenkjenne en hjertestans, alarmere og starte hjerte-lunge-redning innen ett minutt.

Ved Stavanger universitetssykehus ønsker man at alle skal lære eller repetere basal hjerte-lunge-redning. Derfor mottok alle ansatte en personlig opplæringsdukke og fikk se en 24-minutters opplæringsfilm på DVD. Filmen ble vist til grupper på 50 ansatte om gangen hver halvtime, og man kunne utføre hjerte-lunge-redning på dukken samtidig. Det var også mulig å øve seg i egen avdeling eller hjemme. Opplæringen tok ca. 30 minutter per ansatt.

I en ny artikkel viser vi at opplæringen førte til en dobling av antall gode brystkompresjoner målt seks måneder etter opplæringen sammenliknet med utførelsen før

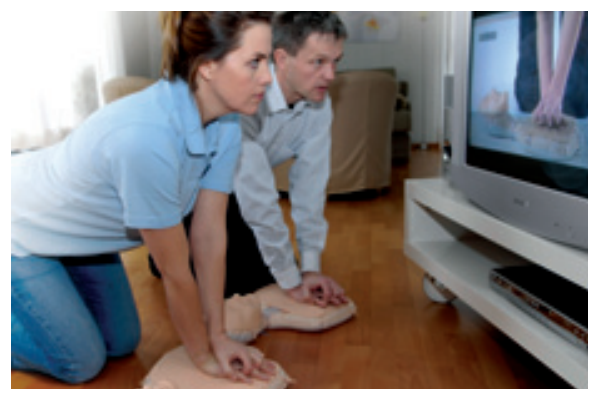

Gjengitt med tillatelse fra Laerdal Medical AS

opplæringen (1). Det var imidlertid ingen signifikant endring $i$ antall gode munn-tilmunn-innblåsinger. Selvopplevd mestring av hjerte-lunge-redning økte fra 3,1 til 3,8 på en skala fra 1 til $5.95 \%$ av de ansatte deltok i opplæringen.

\section{Conrad Bjørshol}

bjco@sus.no

Akuttklinikken

Stavanger universitetssykehus

\section{Litteratur}

Bjørshol CA, Lindner TW, Søreide E et al. Hospital employees improve basic life support skills and confidence with a personal resuscitation manikin and a 24-min video instruction. Resuscitation 2009: 80: 898-902.

\section{Pasientgenotype påvirker terapi ved hepatitt $\mathrm{C}$}

En polymorfisme nær genet $/ L 28 B$ påvirker responsen på hepatitt Cbehandling.

Hepatitt C-behandlingen er dyr, langvarig, har mange bivirkninger og varierende effekt. Man har derfor ønsket å finne markører som kan forutsi responsen. Ved hjelp av genomvide assosiasjonsstudier med 1671 personer som ble behandlet for hepatitt $\mathrm{C}$ har forskere nå vist at en polymorfisme i et gen nær $I L 28 B$ er assosiert med behandlingsrespons (1).

- Vi har lenge individualisert hepatitt Cbehandlingen ut fra viral genotyping. Denne studien gir håp om at vi i fremtiden også kan tilpasse behandlingen til vertsgenotypen, sier lege Olav Dalgard ved Medisinsk avdeling, Oslo universitetssykehus, Rikshospitalet.

- Vertsgenotypen kan, sammen med virusgenotype og andre faktorer, hjelpe oss til å bestemme riktig dosering av medikamentene og varigheten av behandlingen. Hvis genotyping også kan bidra til å identifisere dem som helt sikkert ikke vil ha nytte av den, vil dette være et viktig fremskritt.

\section{Frakturer og dødelighet}

I en kanadisk observasjonsstudie var det sammenheng mellom vertebralfrakturer og hoftebrudd og økt dødsrisiko (CMAJ 2009; 181: 265-71).

Man fulgte 8000 tilfeldig valgte personer ( $\geq 50$ år) i fem år og skilte mellom brudd vertebralt, i bekken, underarm, håndledd, ribbein og hofte og annen lokalisasjon.

De med hoftebrudd i løpet av det første oppfølgingsåret hadde økt dødsrisiko ljustert hasardratio 2,7) sammenliknet med dem uten brudd i oppfølgingsperioden. Intervensjon mot denne type brudd kan muligens øke overlevelsen.

\section{Nevrofibromatose}

De fleste barn med mange og typiske caféau-lait-flekker vil senere tilfredsstille kriteriene for nevrofibromatose. Disse barna bør derfor henvises til spesialistutredning, ifølge forfatterne av en artikkel publisert i Archives of Dermatology 12009; 145: 883-7).

Nevrofibromatose type 1 er en relativt vanlig, autosomalt dominant sykdom. Pasienten utvikler fibromer i sentralnervesystemet og har samtidig karakteristiske, flate og lysebrune flekker på huden (caféau-lait-flekker). De diagnostiske kriteriene inkluderer minst seks slike flekker og to fibromer. I en retrospektiv undersøkelse av 110 barn som hadde vært henvist med café-au-lait-flekker, hadde én av tre fått diagnosen før de var seks år. Disse hadde langt flere flekker (gjennomsnittlig 11 ved henvisningstidspunktet) enn de andre. Bare to barn med flekker som var blitt beskrevet som atypiske fikk diagnosen.

\section{Stafylokokker og atopisk dermatitt}

Kolonisering med gule stafylokokker i seksmånedersalderen kan ha stor betydning for utviklingen av immunsystemet. I en prospektiv unders $ø$ kelse fra Nederland viste det seg at spedbarn som testet positivt på gule stafylokokker, hadde inntil fire ganger så høy risiko som andre for få atopisk dermatitt i løpet av de neste to årene (Arch Pediatr Adolesc Med 2009; 163:

745 -9). Risikoen var særlig stor hos dem som testet positivt minst to ganger. I studien var det inkludert over 1000 barn, som fikk tatt bakterieprøver fra nesen regelmessig fra de var seks uker gamle. 